\title{
Salt Tolerance of Green Soybeans
}

\author{
Akira Nukaya, Masao Masui, Akira Ishida \\ and Takayasu Ogura \\ College of Agriculture, Shizuoka University, Ohya, Shizuoka
}

\begin{abstract}
Summary
Experiments were conducted to determine the effect of diluted sea water on the germination, growth and yield of green soybeans. The germination rate was not significantly different at 0 to $3,000 \mathrm{ppm} \mathrm{Cl} 2$ days after starting the germination test. Seedlings were grown in sand culture for 20 days after seeding. The top dry weight was greatest at 250 and $500 \mathrm{ppm} \mathrm{Cl}$. Green soybeans were grown in sand and soil cultures. Salt injury in sand culture was not found at 0 and $100 \mathrm{ppm} \mathrm{C1.}$ However, it was slight at $250 \mathrm{ppm} \mathrm{Cl}$, and became much more severe with increasing sea water concentrations. The seed fresh weight was greatest at 0 to $250 \mathrm{ppm} \mathrm{C1}$ in sand culture and at 0 to $500 \mathrm{ppm} \mathrm{Cl}$ in soil culture. There was an increase in $\mathrm{Na}$ and $\mathrm{Cl}$ content in the leaves in sand and soil cultures when sea water concentrations were at high $\mathrm{Cl}$ levels. The content of $\mathrm{Cl}$ and exchangeable $\mathrm{Na}$, and $\mathrm{EC}$ value of the soil increased with increasing sea water concentrations.
\end{abstract}

\section{Introduction}

Data from the survey of ions in soluble salts causing salinity $\left(\mathrm{Cl}^{-}, \mathrm{Na}^{+}, \mathrm{SO}_{4}{ }^{2-}, \mathrm{K}^{+}\right.$, $\mathrm{Mg}^{2+}$ and $\mathrm{Ca}^{2+}$ ) in well water (13) indicate that much which is available for irrigation in the coastal greenhouse crop area in the Shizuoka Prefecture is high in salt content. Also, these data show that these salts result from wells being contaminated by sea water. Crops appear affected by the use of salt contaminated well water for irrigation.

Many studies in relation to salt injury to plants have been reported. However, inorganic salts, for example $\mathrm{NaCl}$ or $\mathrm{Na}_{2} \mathrm{SO}_{4}$, were used as a source of excess soluble salts in most studies. Few studies reported have used sea water or river water containing $\mathrm{NaCl}$ and other salts. Moreover, leguminous plants seem to be one of the most sensitive plants to excess soluble salts $(4,15)$. Green soybeans (Glycine $\max$ Merr.) are one of the main crops at Miho, Shimizu, where the highest salinity was detected in well water. Chlorine during one year averaged $549.8 \mathrm{ppm}$. The salt tolerance of green soybeans has not yet been reported. Because it was desirable to know how much salinity green soybeans could tolerate, these

\footnotetext{
Received for publication March 16, 1976
}

experiments were conducted to determine the effect of various concentrations of sea water on the germination, growth of seedlings in sand culture, and growth and yield in sand and soil cultures of green soybeans.

\section{Materials and Methods}

Treatments were made by diluting sea water with tap water or Hoagland's solution (Table $1)$. Sea water concentrations were based on a survey of the $\mathrm{Cl}$ content of well water (13). The sea water diluted with Hoagland's solution was used in sand culture and with tap water in soil culture. Each treatment solution contained $0,50,100,250,500,1,000,2,000$ and $3,000 \mathrm{ppm} \mathrm{Cl}$ diluted from sea water. Tables 2 and 3 show cation concentrations, EC, $\mathrm{pH}$ and osmotic pressure in relation to diluted sea

Table 1. Composition of nutrient solution.

\begin{tabular}{rll}
\hline 1 & $\mathrm{Na}_{2} \mathrm{HPO}_{4} \cdot 12 \mathrm{H}_{2} \mathrm{O}$ & $0.5 \mathrm{mM}$ \\
2 & $\mathrm{~K}_{2} \mathrm{SO}_{4}$ & $3 \mathrm{mM}$ \\
3 & $\mathrm{Ca}\left(\mathrm{NO}_{3}\right)_{2} \cdot 4 \mathrm{H}_{2} \mathrm{O}$ & $4 \mathrm{mM}$ \\
4 & $\mathrm{MgSO}_{4} \cdot 7 \mathrm{H}_{2} \mathrm{O}$ & $2 \mathrm{mM}$ \\
5 & $\mathrm{Mn}$ & $0.5 \mathrm{ppm}\left(\mathrm{MnSO}_{4}\right)$ \\
6 & $\mathrm{Fe}$ & $1 \mathrm{ppm}\left(\mathrm{FeC}_{6} \mathrm{H}_{5} \mathrm{O}_{7} \cdot 5 \mathrm{H}_{2} \mathrm{O}\right)$ \\
7 & $\mathrm{Zn}$ & $0.05 \mathrm{ppm}\left(\mathrm{ZnSO}_{4} \cdot 7 \mathrm{H}_{2} \mathrm{O}\right)$ \\
8 & $\mathrm{Cu}$ & $0.02 \mathrm{ppm}\left(\mathrm{CuSO}_{4} \cdot 5 \mathrm{H}_{2} \mathrm{O}\right)$ \\
9 & $\mathrm{~B}$ & $0.5 \mathrm{ppm}\left(\mathrm{H}_{3} \mathrm{BO}_{3}\right)$ \\
10 & $\mathrm{Mo}$ & $0.05 \mathrm{ppm}\left(\mathrm{Na}_{2} \mathrm{MoO}_{4} \cdot 2 \mathrm{H}_{2} \mathrm{O}\right)$ \\
11 & $\mathrm{pH}=5.7 \sim 5.8$ &
\end{tabular}


Table 2. Cation concentrations, $\mathrm{EC}$ and $\mathrm{pH}$ in relation to sea water diluted with nutrient solution used in water or sand culture.

\begin{tabular}{|c|c|c|c|c|c|c|c|}
\hline \multicolumn{3}{|c|}{ Sea water concentrations } & \multicolumn{4}{|c|}{ Cations (ppm) } & \multirow{2}{*}{$\mathrm{EC} \mathrm{m} v / \mathrm{cm}$} \\
\hline $\mathrm{Cl}$ & $\begin{array}{l}\text { Osmotic } \\
\text { pressure }\end{array}$ & $\%$ & $\mathrm{~K}$ & $\mathrm{Na}$ & $\mathrm{Ca}$ & $\mathrm{Mg}$ & \\
\hline $0^{\mathrm{ppm}}$ & $0.68^{\mathrm{atm}}$ & 0 & 117 & 44 & 232 & 46 & 2.425 \\
\hline 50 & 0.75 & 0.25 & 118 & 69 & 233 & 49 & 2. 435 \\
\hline 100 & 0.82 & 0.50 & 119 & 94 & 234 & 52 & 2. 605 \\
\hline 250 & 1.01 & 1.25 & 123 & 170 & 237 & 61 & 3.030 \\
\hline 500 & 1.33 & 2.50 & 128 & 296 & 242 & 78 & 3. 865 \\
\hline 1,000 & 1.99 & 5.00 & 139 & 548 & 252 & 109 & 4.960 \\
\hline 2,000 & 3.29 & 10.00 & 162 & 1,052 & 271 & 172 & 7.735 \\
\hline 3,000 & 4.60 & 15. $\mathrm{CO}$ & 184 & 1,556 & 291 & 235 & 10. 750 \\
\hline \multicolumn{3}{|c|}{ Sea water $20,500 \mathrm{ppm} \mathrm{Cl}$} & 445 & 10,082 & 393 & 1,262 & 一 \\
\hline
\end{tabular}

Table 3. Cation concentrations, $\mathrm{pH}$ and $\mathrm{EC}$ in relation to sea water diluted with tap water used in soil culture.

\begin{tabular}{|c|c|c|c|c|c|c|c|c|}
\hline \multicolumn{3}{|c|}{ Sea wa.er concentrations } & \multicolumn{4}{|c|}{ Cations (ppm) } & \multirow{2}{*}{$\mathrm{pH}$} & \multirow{2}{*}{$\begin{array}{c}\mathrm{EC} \\
\mathrm{m} \mho / \mathrm{cm}\end{array}$} \\
\hline $\mathrm{Cl}$ & $\begin{array}{l}\text { O. motic } \\
\text { pressure }\end{array}$ & $\%$ & $\mathrm{~K}$ & $\mathrm{Na}$ & $\mathrm{Ca}$ & $\mathrm{Mg}$ & & \\
\hline $0^{\mathrm{ppm}}$ & $0 \quad$ atm & 0 & 0 & 0 & 0 & 0 & 7.00 & 0.135 \\
\hline 50 & 0.07 & 0.25 & 1 & 25 & 1 & 3 & 7.19 & 0.290 \\
\hline 100 & 0.14 & 0.50 & 2 & 50 & 2 & 6 & 7.35 & 0.460 \\
\hline 250 & 0.33 & 1. 25 & 6 & 126 & 5 & 16 & 7.58 & 0.910 \\
\hline 500 & 0.65 & 2.50 & 11 & 252 & 10 & 32 & 7.62 & 1.655 \\
\hline 1,000 & 1.31 & 5.00 & 22 & 504 & 20 & 63 & 7.52 & 2.990 \\
\hline 2,000 & 2.61 & 10.00 & 45 & 1,008 & 39 & 126 & 7. 62 & 5.470 \\
\hline 3,000 & 3.92 & 15.00 & 67 & 1,512 & 59 & 189 & 7.68 & 7.730 \\
\hline \multicolumn{3}{|c|}{ Sea water $20,500 \mathrm{ppm} \mathrm{Cl}$} & 445 & 10,082 & 393 & 1,262 & - & - \\
\hline
\end{tabular}

water solutions. Osmotic pressure was determined by the cryoscopic method. The variety used was cv. 'Hakucho' which is grown by the commercia! growers in Miho, Shimizu.

Experiment I-Seed Germination: The purpose of the experiment was to determine the effect of diluted sea water on germination. The diluted sea water treatments were replicated 4 times. Forty seeds were placed on filter paper in a petri dish. The filter paper was moistened with sea water diluted with distilled water. Seeds were incubated at $25^{\circ} \mathrm{C}$. The sea water used was autoclaved to prevent seeds from rotting.

Experiment II-Salt Tolerance of the Seedlings: The objective of this experiment was to evaluate the effect of diluted sea water on seedlings grown in sand culture for 20 days. Eight sea water solutions of $0,50,100,250$, $500,1,000,2,000$ and $3,000 \mathrm{ppm} \mathrm{Cl}$ diluted with $1 / 5$ Hoagland's solution applied to seed- lings resulted in osmotic pressure of 0.17 , $0.21,0.28,0.47,0.79,1.45,2.75$ and 4.06 atm, respectively (Table 5 ). Seeds were planted directly in black plastic containers $(43 \times 35$ $\times 10 \mathrm{~cm}$ ) filled with sand and placed in a plastic house on September 22, 1973. After germination seedlings were thinned to 20 uniform plants per container. Treatment was carried out beginning on the date seeded and continued for 20 days.

Experiment III-Sand Culture : The study of salt tolerance of green soybeans was made in a sand like that of the Miho, Shimizu area. Twenty-seven seeds were planted directly in a wooden container $(40 \times 40 \times 12 \mathrm{~cm})$ filled with sand and placed in a plastic house on March 9, 1974. Seedlings were thinned to 9 uniform plants per container after germination. Diluted sea water solutions were applied to the sand medium from March 29, when the soybean plants were in the 3 to 4 leaf stage, to May. 
31 , at which time the entire plant was sampled. These treatments were made twice on clear days and once on cloudy days. There was no treatment on rainy days. The seven sea water solutions diluted with Hoagland's solution were replicated 7 times.

Symptoms of salt injury and growth were evaluated on May 1, 1974 and at harvest time, respectively. The main elements in the leaves were analyzed. Plant salt injury symptoms were evaluated as follows : 0-no marked symptoms of injury developed; 0.5 -chlorosis was shown at lower leaves; 1 -chlorosis at lower leaves advanced to necrosis ; 2 -middle leaves showed chlorosis accompanied with degree of ' 1 '; and 3-lower leaves were dead. Middle and upper leaves showed necrosis and some plants were dead (see Table 6).

Experiment IV-Soil Culture ; To determine the effect of diluted sea water, green soybeans were cultured in soil. Twenty-seven seeds were planted directly into a wooden container $(40 \times 40 \times 12 \mathrm{~cm})$ filled with paddy soil, and placed in a plastic house on September 25, 1973. All soils were mixed with the following fertilizers-2 $\mathrm{g} \mathrm{N}, 4 \mathrm{~g} \mathrm{P}_{2} \mathrm{O}_{5}, 3 \mathrm{~g} \mathrm{~K}_{2} \mathrm{O}$, and $25 \mathrm{~g}$ $\mathrm{CaO}$. After germination, seedlings were thinned to 9 uniform plants per container. Treatments were applied from October 15 to December 11,1973 at the same growth stage as in sand culture. Treatments consisting of 8 sea water solutions were diluted with tap water. Each was replicated 8 times. At harvest the dry weight of leaves, stems, roots and pods, and the fresh and dry weights of seed were measured. The main elements in the leaves and chemical properties of the soil were determined at the end of the experiment.

Methods of Plant Analysis: An aliquot of dry sample was ashed at $550^{\circ} \mathrm{C}$ and extracted with $\mathrm{HCl}$, for determining $\mathrm{K}, \mathrm{Na}, \mathrm{Ca}$, and $\mathrm{Mg}$ by an Atomic absorption spectrophotometer and $\mathrm{P}$ by the Molybdenum blue colorimetric method. $\mathrm{N}$ was determined by the Kjeldahl method. $\mathrm{Cl}$ was determined by the mercuric thiocyanate colorimetric method, after ashing the dry sample at $550^{\circ} \mathrm{C}$ and extraction with hot water.

Methods of Soil Analysis : Nitrate-N was determined by the phenoldisulphonic acid method. Phosphorous (Truog), Cl (soil/water
$=1 / 5$ ), and exchangeable $\mathrm{K}, \mathrm{Ca}, \mathrm{Na}$ and $\mathrm{Mg}$ ( $1 \mathrm{~N}$ ammonium acetate) were determined by the same analysis used for plant. Electric conductivity $(1: 5)$ was measured by the Tōa Model CM-IDB meter and $\mathrm{pH}$ was determined by the glass electrode method.

\section{Results}

Germination :

Table 4 shows results of the germination test. The germination rate 1 day after starting was $28.0 \%$ at $2,000 \mathrm{ppm} \mathrm{Cl}$ and $25.0 \%$ at $3,000 \mathrm{ppm} \mathrm{Cl}$. These values were about $50 \%$ less than those that germinated between 0 and $1,000 \mathrm{ppm} \mathrm{Cl}$. However, after 2 and 3 days the germination rate was not significantly different among the treatments. Even at 3,000 $\mathrm{ppm} \mathrm{Cl}$ it was $99.4 \%$ after 3 days.

Seedlings:

As shown in Table 5, leaf, stem and root

Table 4. Effect of sea water concentrations on germination rate of soybean seeds $(\%)$.

\begin{tabular}{c|c|c|c|c}
\hline \multicolumn{2}{c|}{$\begin{array}{c}\text { Sea water } \\
\text { concent rations }\end{array}$} & \multicolumn{3}{|c}{$\begin{array}{c}\text { Days after starting the } \\
\text { germination test }\end{array}$} \\
\cline { 2 - 5 } $\mathrm{Cl}$ & $\begin{array}{c}\text { Osmotic } \\
\text { pressure }\end{array}$ & $1^{*}$ & 2 & 3 \\
\hline 0 & 0 & $43.8^{\mathrm{a}}$ & $96.9^{\mathrm{ab}}$ & $100.0^{\mathrm{a}}$ \\
50 & 0.07 & $41.0^{\mathrm{a}}$ & $95.0^{\mathrm{b}}$ & $98.1^{\mathrm{b}}$ \\
100 & 0.14 & $49.8^{\mathrm{a}}$ & $95.0^{\mathrm{b}}$ & $99.4^{\mathrm{ab}}$ \\
250 & 0.33 & $50.6^{\mathrm{a}}$ & $99.4^{\mathrm{a}}$ & $99.4^{\mathrm{ab}}$ \\
500 & 0.65 & $48.3^{\mathrm{a}}$ & $96.9^{\mathrm{ab}}$ & $100.0^{\mathrm{a}}$ \\
1,000 & 1.31 & $46.3^{\mathrm{a}}$ & $97.5^{\mathrm{ab}}$ & $100.0^{\mathrm{a}}$ \\
2,000 & 2.61 & $28.0^{\mathrm{b}}$ & $91.3^{\mathrm{c}}$ & $96.3^{\mathrm{c}}$ \\
3,000 & 3.92 & $25.0^{\mathrm{b}}$ & $96.3^{\mathrm{ab}}$ & $99.4^{\mathrm{ab}}$ \\
\hline
\end{tabular}

* : Means followed by the same letter with in columns are not significantly different at the $5 \%$ level, as determined by Duncan's multiple range test.

Table 5. Effect of sea water concentrations on the growth of soybean seedlings in sand culture ( $g$ of dry wt.).

\begin{tabular}{|c|c|c|c|c|c|}
\hline \multicolumn{2}{|c|}{$\begin{array}{l}\text { Sea water } \\
\text { concentrations }\end{array}$} & \multirow{2}{*}{$\begin{array}{c}\text { Leaves* } \\
(L)\end{array}$} & \multirow{2}{*}{$\begin{array}{l}\text { Stems } \\
(S)\end{array}$} & \multirow{2}{*}{$\begin{array}{l}\text { Roots } \\
(R)\end{array}$} & \multirow{2}{*}{$\begin{array}{c}\text { Whole } \\
\text { plant } \\
(L+S+R)\end{array}$} \\
\hline $\mathrm{Cl}$ & $\begin{array}{l}\text { Osmotic } \\
\text { pressure }\end{array}$ & & & & \\
\hline $\begin{array}{r}\mathrm{ppn} \\
0\end{array}$ & $0.17^{\text {atm }}$ & 1. $28^{\mathrm{c}}$ & $0.93^{\mathrm{cd}}$ & $0.95^{\mathrm{b}}$ & $3.16^{\mathrm{d}}$ \\
\hline 50 & 0.21 & $1.63^{b}$ & $1.05^{\mathrm{bcd}}$ & $0.98^{\mathrm{b}}$ & 3. $66^{\mathrm{bc}}$ \\
\hline 100 & 0.28 & $1.60^{\mathrm{b}}$ & $1.08^{\mathrm{bc}}$ & $1.05^{\mathrm{ab}}$ & 3. $73^{b}$ \\
\hline 250 & 0.47 & $1.53^{\mathrm{b}}$ & $1.55^{\mathrm{a}}$ & 1. $10^{\mathrm{a}}$ & 4. $18^{\mathrm{a}}$ \\
\hline 500 & 0.79 & $1.83^{\mathrm{a}}$ & 1. $25^{\mathrm{b}}$ & 1. $05^{\mathrm{ab}}$ & 4. $13^{\mathrm{a}}$ \\
\hline 1,000 & 1.45 & $1.35^{c}$ & $0.98^{\mathrm{cd}}$ & 1. $05^{\mathrm{ab}}$ & $3.38^{\mathrm{cd}}$ \\
\hline 2,000 & 2. 75 & $0.90^{\mathrm{d}}$ & $0.83^{\mathrm{cd}}$ & $0.78^{\mathrm{c}}$ & $2.51^{\mathrm{e}}$ \\
\hline 3,000 & 4.06 & $0.40^{e}$ & $0.58^{\mathrm{e}}$ & $0.55^{\mathrm{d}}$ & $1.53^{\mathrm{f}}$ \\
\hline
\end{tabular}

*: Means followed by the same letter with in columns are not significantly different at the $5 \%$ level, as determined by Duncan's multiple range test. 
Table 6. Effect of sea water concentrations on the growth and salt injury symptoms of green soybeans in sand culture ( $\mathrm{g}$ of each part for growth).

\begin{tabular}{c|c|c|c|c|c|c|c|c}
\hline $\begin{array}{c}\text { Cl concn } \\
(\mathrm{ppm})\end{array}$ & $\begin{array}{c}\text { Leaves* } \\
\text { dry wt }\end{array}$ & $\begin{array}{c}\text { Stems } \\
\text { dry wt }\end{array}$ & $\begin{array}{c}\text { Roots } \\
\text { dry wt }\end{array}$ & $\begin{array}{c}\text { Pods } \\
\text { dry wt }\end{array}$ & $\begin{array}{c}\text { Seeds } \\
\text { fresh wt }\end{array}$ & $\begin{array}{c}\text { Seeds } \\
\text { dry wt }\end{array}$ & $\begin{array}{c}\text { Whole plant } \\
\text { dry wt }\end{array}$ & $\begin{array}{c}\text { Salt in jury } \\
\text { symptoms }\end{array}$ \\
\hline 0 & $29.6^{\mathrm{a}}$ & $27.6^{\mathrm{a}}$ & $13.1^{\mathrm{a}}$ & $24.2^{\mathrm{a}}$ & $82.3^{\mathrm{a}}$ & $23.4^{\mathrm{a}}$ & $117.9^{\mathrm{a}}$ & 0 \\
100 & $28.7^{\mathrm{ab}}$ & $23.3^{\mathrm{b}}$ & $13.9^{\mathrm{a}}$ & $23.0^{\mathrm{ab}}$ & $84.0^{\mathrm{a}}$ & $23.4^{\mathrm{a}}$ & $112.3^{\mathrm{a}}$ & 0 \\
250 & $23.6^{\mathrm{bc}}$ & $19.1^{\mathrm{c}}$ & $10.0^{\mathrm{b}}$ & $21.3^{\mathrm{b}}$ & $80.2^{\mathrm{a}}$ & $22.4^{\mathrm{a}}$ & $96.4^{\mathrm{b}}$ & $0 \sim 0.5$ \\
500 & $24.1^{\mathrm{bc}}$ & $16.2^{\mathrm{c}}$ & $8.3^{\mathrm{bc}}$ & $18.2^{\mathrm{c}}$ & $56.2^{\mathrm{b}}$ & $14.3^{\mathrm{b}}$ & $81.1^{\mathrm{c}}$ & 1 \\
1,000 & $20.1^{\mathrm{c}}$ & $11.8^{\mathrm{d}}$ & $6.2^{\mathrm{cd}}$ & $12.0^{\mathrm{d}}$ & $30.0^{\mathrm{c}}$ & $6.6^{\mathrm{c}}$ & $56.7^{\mathrm{d}}$ & 2 \\
2,000 & $12.1^{\mathrm{d}}$ & $10.0^{\mathrm{d}}$ & $3.9^{\mathrm{de}}$ & $4.2^{\mathrm{e}}$ & $8.3^{\mathrm{d}}$ & $1.8^{\mathrm{d}}$ & $32.0^{\mathrm{e}}$ & $2 \sim 3$ \\
3,000 & $6.7^{\mathrm{e}}$ & $4.5^{\mathrm{e}}$ & $2.0^{\mathrm{e}}$ & $1.8^{\mathrm{f}}$ & $2.6^{\mathrm{d}}$ & $0.3^{\mathrm{d}}$ & $15.3^{\mathrm{f}}$ & 3 \\
\hline
\end{tabular}

* : Means followed by the same letter with in columns are not significantly different at the $5 \%$ level, as determined by Duncan's multiple range test.

weights were greatest at $500 \mathrm{ppm} \mathrm{Cl,} 250 \mathrm{ppm}$ $\mathrm{Cl}$ and $250 \mathrm{ppm} \mathrm{Cl}$, respectively. The whole plant dry weight was greatest at 250 and 500 $\mathrm{ppm} \mathrm{Cl}$. As sea water concentrations were increased from 0 to $250 \mathrm{ppm} \mathrm{Cl}$ the whole plant dry weight was increased. However, it was markedly decreased with increasing sea water concentrations from 1,000 to $3,000 \mathrm{ppm}$ $\mathrm{Cl}$. The growth at $0 \mathrm{ppm} \mathrm{Cl}$ was almost the same as that at $1,000 \mathrm{ppm} \mathrm{Cl}$.

Sand Culture :

Growth-The growth data are given in Table 6. The whole plant dry weight was greatest at 0 and $100 \mathrm{ppm} \mathrm{Cl}$ and decreased with increasing sea water concentrations from 250 to $3,000 \mathrm{ppm} \mathrm{Cl}$. The value of whole plant dry weight was $117.9 \mathrm{~g}$ at $0 \mathrm{ppm} \mathrm{Cl}$ and $15.3 \mathrm{~g}$ at $3,000 \mathrm{ppm} \mathrm{Cl}$. There was no significant difference in the seed fresh weight between 0 and $250 \mathrm{ppm} \mathrm{Cl}$. However, as sea water concentrations were increased from 500 to 3,000 ppm $\mathrm{Cl}$ the seed fresh weight markedly decreased. The seed fresh weight was $68 \%$, $36 \%, 10 \%$ and $3 \%$, at $500,1,000,2,000$ and $3,000 \mathrm{ppm} \mathrm{Cl}$, respectively, as compared to the weight at $0 \mathrm{ppm} \mathrm{Cl}$. The leaf, stem, root and pod dry weights were similar to the whole plant dry weight.

The progress of visible salt injury on leaves was as follows : 1) Leaf margins showed slight chlorosis. 2) Injury was much more advanced, and necrosis and withering of leaves developed and 3) Leaves became brown and dropped. During the experiment, necrosis was observed 16 days after the beginning of the treatments (April $14 \mathrm{th}$ ) at 2,000 and $3,000 \mathrm{ppm} \mathrm{Cl}$, and after 22 days (April 20 th) at 500 and 1,000 ppm Cl. Withered plants were noted after 40 days. Fifty per cent of the plants were dead at 3,000 ppm $\mathrm{Cl} 10$ days before harvest (May 20 th). As shown in Table 6 , salt injury was not found at 0 and $100 \mathrm{ppm} \mathrm{Cl}$, however, chlorosis was found on lower leaves in some plants at $250 \mathrm{ppm} \mathrm{Cl}$. Salt injury became much more severe with increasing sea water concentrations from 250 to $3,000 \mathrm{ppm} \mathrm{Cl}$.

Mineral Composition in the Leaves-Results are summarized in Table 7 . The content of $\mathrm{Cl}$ and $\mathrm{Na}$ increased almost in proportion to sea water concentrations. The content of $\mathrm{N}$ and $\mathrm{P}$ was greater at 2,000 and $3,000 \mathrm{ppm} \mathrm{Cl}$. The content of $\mathrm{Ca}$ and $\mathrm{Mg}$ was greater from

Table 7. Effect of sea water concentrations on the main elements of green soybean leaves in sand culture ( $\%$ of dry matter).

\begin{tabular}{c|l|l|l|l|l|l|ll}
\hline \hline $\mathrm{Cl}$ concn & $\mathrm{N}^{*}$ & $\mathrm{P}$ & $\mathrm{K}$ & $\mathrm{Na}$ & $\mathrm{Ca}$ & $\mathrm{Mg}$ & $\mathrm{Cl}$ \\
\hline 0 & $\mathrm{ppm}$ & $2.49^{\mathrm{e}}$ & $0.13^{\mathrm{d}}$ & $2.45^{\mathrm{a}}$ & $0.10^{\mathrm{d}}$ & $2.52^{\mathrm{bc}}$ & $0.95^{\mathrm{c}}$ & $1.90^{\mathrm{e}}$ \\
100 & $2.60^{\mathrm{de}}$ & $0.12^{\mathrm{d}}$ & $2.31^{\mathrm{a}}$ & $0.13^{\mathrm{d}}$ & $2.77^{\mathrm{b}}$ & $1.08^{\mathrm{b}}$ & $3.32^{\mathrm{d}}$ \\
250 & $2.60^{\mathrm{de}}$ & $0.11^{\mathrm{d}}$ & $2.26^{\mathrm{ab}}$ & $0.36^{\mathrm{c}}$ & $3.18^{\mathrm{a}}$ & $1.18^{\mathrm{a}}$ & $5.42^{\mathrm{c}}$ \\
500 & $2.90^{\mathrm{cd}}$ & $0.13^{\mathrm{d}}$ & $2.40^{\mathrm{a}}$ & $0.52^{\mathrm{b}}$ & $3.08^{\mathrm{a}}$ & $1.14^{\mathrm{ab}}$ & $6.46^{\mathrm{ab}}$ \\
1,000 & $3.18^{\mathrm{c}}$ & $0.17^{\mathrm{c}}$ & $2.26^{\mathrm{ab}}$ & $0.55^{\mathrm{b}}$ & $2.79^{\mathrm{b}}$ & $1.11^{\mathrm{ab}}$ & $7.21^{\mathrm{a}}$ \\
2,000 & $3.57^{\mathrm{b}}$ & $0.23^{\mathrm{b}}$ & $2.18^{\mathrm{ab}}$ & $0.63^{\mathrm{b}}$ & $2.33^{\mathrm{c}}$ & $1.06^{\mathrm{c}}$ & $7.07^{\mathrm{a}}$ \\
3,000 & $4.14^{\mathrm{a}}$ & $0.20^{\mathrm{a}}$ & $1.97^{\mathrm{b}}$ & $0.77^{\mathrm{a}}$ & $1.71^{\mathrm{d}}$ & $0.86^{\mathrm{d}}$ & $6.71^{\mathrm{ab}}$ \\
\hline
\end{tabular}

*: Means followed by the same letter within columns are not significantly different at the $5 \%$ level, as determined by Duncan's multiple range test. 
Table 8. Effect of sea water concentrations on the growth of green soybeans in soil culture ( $\mathrm{g}$ of each part).

\begin{tabular}{c|c|c|c|c|c|c|c}
\hline $\begin{array}{c}\text { Cl concn } \\
(\mathrm{ppm})\end{array}$ & $\begin{array}{c}\text { Leaves* } \\
\text { dry wt }\end{array}$ & $\begin{array}{c}\text { Stems } \\
\text { dry wt }\end{array}$ & $\begin{array}{c}\text { Roots } \\
\text { dry wt }\end{array}$ & $\begin{array}{c}\text { Pods } \\
\text { dry wt }\end{array}$ & $\begin{array}{c}\text { Seeds } \\
\text { fresh wt }\end{array}$ & $\begin{array}{c}\text { Seeds } \\
\text { dry wt }\end{array}$ & $\begin{array}{c}\text { Whole plant } \\
\text { dry wt }\end{array}$ \\
\hline 0 & $11.7^{\mathrm{ab}}$ & $7.7^{\mathrm{ab}}$ & $3.3^{\mathrm{a}}$ & $13.9^{\mathrm{a}}$ & $24.6^{\mathrm{a}}$ & $7.5^{\mathrm{abc}}$ & $44.1^{\mathrm{a}}$ \\
50 & $10.7^{\mathrm{b}}$ & $7.0^{\mathrm{bc}}$ & $3.2^{\mathrm{a}}$ & $11.5^{\mathrm{b}}$ & $26.5^{\mathrm{a}}$ & $7.9^{\mathrm{ab}}$ & $40.3^{\mathrm{a}}$ \\
100 & $11.9^{\mathrm{ab}}$ & $7.7^{\mathrm{ab}}$ & $3.3^{\mathrm{a}}$ & $12.9^{\mathrm{ab}}$ & $28.0^{\mathrm{a}}$ & $8.6^{\mathrm{a}}$ & $44.3^{\mathrm{a}}$ \\
250 & $13.4^{\mathrm{a}}$ & $8.3^{\mathrm{a}}$ & $3.6^{\mathrm{a}}$ & $12.8^{\mathrm{ab}}$ & $25.7^{\mathrm{a}}$ & $7.0^{\mathrm{bc}}$ & $45.0^{\mathrm{a}}$ \\
500 & $11.6^{\mathrm{ab}}$ & $7.1^{\mathrm{ab}}$ & $3.1^{\mathrm{ab}}$ & $12.4^{\mathrm{ab}}$ & $24.6^{\mathrm{a}}$ & $7.2^{\mathrm{bc}}$ & $41.5^{\mathrm{a}}$ \\
1,000 & $10.7^{\mathrm{b}}$ & $5.8^{\mathrm{c}}$ & $2.5^{\mathrm{bc}}$ & $8.8^{\mathrm{c}}$ & $19.5^{\mathrm{b}}$ & $5.8^{\mathrm{d}}$ & $33.6^{\mathrm{b}}$ \\
2,000 & $8.4^{\mathrm{c}}$ & $4.5^{\mathrm{d}}$ & $1.9^{\mathrm{cd}}$ & $3.9^{\mathrm{d}}$ & $8.6^{\mathrm{c}}$ & $2.2^{\mathrm{e}}$ & $20.8^{\mathrm{c}}$ \\
$3 ; 000$ & $9.6^{\mathrm{bc}}$ & $4.0^{\mathrm{d}}$ & $1.7^{\mathrm{d}}$ & $2.1^{\mathrm{d}}$ & $4.0^{\mathrm{d}}$ & $1.0^{\mathrm{e}}$ & $18.4^{\mathrm{c}}$ \\
\hline
\end{tabular}

*: Means followed by the same letter within columns are not significantly different at the $5 \%$ level, as determined by Duncan's multiple range test.

Table 9. Effect of sea water concentrations on the main elements of green soybean leaves in soil culture ( $\%$ of dry matter).

\begin{tabular}{c|c|c|c|c|c|c|cc}
\hline \hline $\mathrm{Cl}$ concn & $\mathrm{N}^{*}$ & $\mathrm{P}$ & $\mathrm{K}$ & $\mathrm{Na}$ & $\mathrm{Ca}$ & $\mathrm{Mg}$ & $\mathrm{Cl}$ \\
\hline 0 & $2.03^{\mathrm{c}}$ & $0.042^{\mathrm{c}}$ & $1.46^{\mathrm{c}}$ & $0.082^{\mathrm{d}}$ & $3.74^{\mathrm{d}}$ & $0.68^{\mathrm{d}}$ & $0.58^{\mathrm{d}}$ \\
50 & $2.08^{\mathrm{bc}}$ & $0.041^{\mathrm{c}}$ & $1.46^{\mathrm{c}}$ & $0.083^{\mathrm{d}}$ & $4.05^{\mathrm{cd}}$ & $0.68^{\mathrm{d}}$ & $0.56^{\mathrm{d}}$ \\
100 & $2.01^{\mathrm{c}}$ & $0.043^{\mathrm{c}}$ & $1.26^{\mathrm{c}}$ & $0.105^{\mathrm{d}}$ & $4.27^{\mathrm{bc}}$ & $0.70^{\mathrm{d}}$ & $0.56^{\mathrm{d}}$ \\
250 & $2.06^{\mathrm{bc}}$ & $0.050^{\mathrm{c}}$ & $1.25^{\mathrm{c}}$ & $0.090^{\mathrm{d}}$ & $4.03^{\mathrm{cd}}$ & $0.68^{\mathrm{d}}$ & $0.75^{\mathrm{d}}$ \\
500 & $1.99^{\mathrm{c}}$ & $0.050^{\mathrm{c}}$ & $1.28^{\mathrm{c}}$ & $0.098^{\mathrm{d}}$ & $5.19^{\mathrm{a}}$ & $0.80^{\mathrm{c}}$ & $1.30^{\mathrm{d}}$ \\
1,000 & $2.38^{\mathrm{b}}$ & $0.074^{\mathrm{b}}$ & $1.46^{\mathrm{c}}$ & $0.176^{\mathrm{c}}$ & $5.05^{\mathrm{a}}$ & $0.88^{\mathrm{ab}}$ & $4.76^{\mathrm{c}}$ \\
2,000 & $3.31^{\mathrm{a}}$ & $0.113^{\mathrm{a}}$ & $1.86^{\mathrm{b}}$ & $0.345^{\mathrm{b}}$ & $4.62^{\mathrm{b}}$ & $0.94^{\mathrm{a}}$ & $5.90^{\mathrm{b}}$ \\
3,000 & $3.59^{\mathrm{a}}$ & $0.121^{\mathrm{a}}$ & $2.11^{\mathrm{a}}$ & $0.450^{\mathrm{a}}$ & $3.92^{\mathrm{cd}}$ & $0.86^{\mathrm{bc}}$ & $7.80^{\mathrm{a}}$ \\
\hline
\end{tabular}

* : Means followed by the same letter within columns are not significantly different at the $5 \%$ level, as determined by Duncan's multiple range test.

250 to $1,000 \mathrm{ppm} \mathrm{Cl}$. There was no significant difference in $\mathrm{K}$ content.

Soil Culture :

Growth-Table 8 shows the effect of sea water concentrations on growth. The seed fresh weight was not significantly different between 0 and $500 \mathrm{ppm} \mathrm{Cl}$, but it was markedly decreased with increasing sea water concentrations from 1,000 to $3,000 \mathrm{ppm} \mathrm{Cl}$. The percentage of the seed fresh weight compared to $0 \mathrm{ppm} \mathrm{Cl}$ was $79 \%, 35 \%$ and $16 \%$ at 1,000 , 2,000 and $3,000 \mathrm{ppm} \mathrm{Cl}$, respectively.

Sea water concentrations above $1,000 \mathrm{ppm}$ $\mathrm{Cl}$ caused a decrease in the top, leaf, stem, root and pod dry weights. These conditions were similar to that of the seed fresh weight. Although the salt injury in soil culture was almost the same as that in sand culture, the degree of injury and number of dead plants were less in soil culture than in sand culture.

Mineral Composition in the Leaves-Table 9 shows the effect of sea water concentrations on the main elements in the leaves. $\mathrm{Cl}$ and $\mathrm{Na}$ were increased when sea water concentra- tions increased. However, they were not significantly different between 0 to $500 \mathrm{ppm} \mathrm{Cl}$. The content of $\mathrm{N}, \mathrm{P}, \mathrm{K}$ and $\mathrm{Mg}$ was considerably higher at 2,000 and $3,000 \mathrm{ppm} \mathrm{Cl}$. Ca accumulated to a much greater degree at 500 and $1,000 \mathrm{ppm} \mathrm{Cl}$ than at other concentrations.

Chemical Composition in the Soil-Chemical properties of the soil at the termination of the experiment are shown in Table 10. The amount of $\mathrm{Cl}$, exchangeable $\mathrm{Na}, \mathrm{K}$ and $\mathrm{Mg}$, and $\mathrm{EC}$ value were increased with increasing sea water concentrations. The Ca content was greater at 500 and $1,000 \mathrm{ppm} \mathrm{Cl}$. There was no significant difference in $\mathrm{pH}, \mathrm{NO}_{3}-\mathrm{N}$ and $\mathrm{P}$ levels.

\section{Discussion}

It is well known that the delay in emergence and also the decreased germination percentages in many crops are aggravated by higher levels of salinity $(2,3,4,5,16)$. However, Lunin et al (11) reported that the effect of three highest salt levels (ECe values of $8,12,16 \mathrm{mmho} / \mathrm{cm}$ ) applied prior to germination (Contender green 
Table 10. Soil chemical properties at the termination of the green soybean experiment.

\begin{tabular}{|c|c|c|c|c|c|c|c|c|c|}
\hline \multirow{2}{*}{$\begin{array}{c}\text { Cl concn } \\
(\mathrm{ppm})\end{array}$} & \multirow{2}{*}{$\begin{array}{c}\mathrm{NO}_{3}-\mathrm{N}^{*} \\
(\mathrm{ppm})\end{array}$} & \multirow{2}{*}{$\begin{array}{c}\mathrm{P}(\text { Truog }) \\
(\mathrm{ppm})\end{array}$} & \multicolumn{4}{|c|}{ Exchangeable cations $(\mathrm{me} / 100 \mathrm{~g})$} & \multirow{2}{*}{$\begin{array}{c}\mathrm{Cl} \\
(\mathrm{ppm})\end{array}$} & \multirow{2}{*}{$\begin{array}{c}\mathrm{EC} \mathrm{m} \mho / \mathrm{cm} \\
(1: 5)\end{array}$} & \multirow{2}{*}{$\begin{array}{c}\mathrm{pH} \\
\left(\mathrm{H}_{2} \mathrm{O}\right)\end{array}$} \\
\hline & & & $\mathrm{K}$ & $\mathrm{Na}$ & $\mathrm{Ca}$ & $\mathrm{Mg}$ & & & \\
\hline 0 & $79^{\mathrm{a}}$ & $105^{\mathrm{a}}$ & $0.66^{\mathrm{e}}$ & $0.48^{f}$ & $6.52^{\mathrm{b}}$ & $0.86^{\mathrm{e}}$ & $89^{f}$ & $0.62^{\mathbf{e}}$ & $5.84^{a}$ \\
\hline 50 & $89^{\mathrm{a}}$ & $100^{\mathrm{a}}$ & $0.65^{\mathrm{e}}$ & $0.60^{\mathrm{f}}$ & $6.52^{\mathrm{b}}$ & $0.88^{\mathrm{e}}$ & $182^{\text {ef }}$ & $0.67^{\mathrm{e}}$ & $5.50^{\mathrm{d}}$ \\
\hline 100 & $81^{\mathrm{a}}$ & $98^{\mathrm{a}}$ & $0.63^{\mathrm{e}}$ & $0.74^{\mathrm{ef}}$ & $6.29^{\mathrm{b}}$ & $0.93^{\mathrm{de}}$ & $259^{\text {ef }}$ & $0.67^{\mathrm{e}}$ & $5.67^{\mathrm{bc}}$ \\
\hline 250 & $72^{\mathrm{a}}$ & $94^{\mathrm{a}}$ & $0.67^{\mathrm{e}}$ & 1. $15^{\mathrm{e}}$ & 6. $60^{\mathrm{b}}$ & $1.03^{\mathrm{de}}$ & $451^{\mathrm{e}}$ & $0.78^{\mathrm{de}}$ & $5.79^{\mathrm{ab}}$ \\
\hline 500 & $84^{\mathrm{a}}$ & $97^{\mathrm{a}}$ & $0.75^{\mathrm{d}}$ & 2. $22^{\mathrm{d}}$ & $7.09^{\mathrm{a}}$ & $1.21^{\mathrm{d}}$ & $867^{\mathrm{d}}$ & $0.96^{\mathrm{d}}$ & $5.59^{\mathrm{cd}}$ \\
\hline 1,000 & $74^{\mathrm{a}}$ & $103^{\mathrm{a}}$ & $0.81^{\mathrm{c}}$ & 3. $69^{\mathrm{c}}$ & $6.81^{\mathrm{a}}$ & $1.55^{c}$ & $1,498^{\mathrm{c}}$ & $1.21^{\mathrm{c}}$ & $5.56^{\mathrm{cd}}$ \\
\hline 2,000 & $85^{\mathrm{a}}$ & $104^{\mathrm{a}}$ & $0.90^{\mathrm{b}}$ & 6. $30^{\mathrm{b}}$ & $6.64^{\mathrm{b}}$ & $2.39^{\mathrm{b}}$ & $2,876^{\mathrm{b}}$ & $1.85^{b}$ & $5.44^{\mathrm{d}}$ \\
\hline 3,000 & $72^{\mathrm{a}}$ & $99^{a}$ & $0.97^{\mathrm{a}}$ & 8. $77^{a}$ & $6.48^{\mathrm{b}}$ & $3.01^{\mathrm{a}}$ & $3,794^{\mathrm{a}}$ & $2.28^{\mathrm{a}}$ & $5.16^{\mathrm{e}}$ \\
\hline
\end{tabular}

*: Means followed by the same letter with in columns are not significantly different at the $5 \%$ level, as determined by Duncan's multiple range test.

beans) was evident in delayed germination but with no significant difference in per cent germination. Similar results for green beans were noted by Bernstein and Pearson (4). According to other investigators $(7,9)$ it seems the effect of high salt solution applied to the seed is not due to the kind of salt or osmotic pressure, but rather is due to certain enzymatic or hormonal activities which take place within the seed due to salinity or osmotic pressure during treatment.

It is noteworthy that the growth at 250 and $500 \mathrm{ppm} \mathrm{Cl}$ was superior to that at $0 \mathrm{ppm} \mathrm{Cl}$ during the first 20 days after seeding. However, the seed fresh weight at $500 \mathrm{ppm} \mathrm{Cl}$ in sand culture was not only less than that at 0 ppm $\mathrm{Cl}$, but also the top dry weight at 500 ppm $\mathrm{Cl}$ was significantly lower than that at $0 \mathrm{ppm} \mathrm{Cl}$. The content of $\mathrm{Cl}, \mathrm{Na}$ and $\mathrm{Mg}$ in the diluted sea water solution was markedly increased with increasing amounts of sea water, as shown in Tables 2 and 3. It appeared that these ions stimulated growth at 250 and 500 $\mathrm{ppm} \mathrm{Cl}$ in the early growing stage. Lunin et al (11) found that there was no difference in the growth of bean seedlings at the two lower levels (ECe values of 2 and $4 \mathrm{mmhos} / \mathrm{cm}$ ) of salinization. Osawa(15) stated that stimulative effects of 1,000 or $2,000 \mathrm{ppm} \mathrm{NaCl}$ on the vegetative growth of such crops, pak-choi, cabbage, radish, chinese cabbage, celery and tomato might be due to $\mathrm{Na}$ in most cases. Weddin and Struckmeyer (18) also reported that tobacco grown at low $\mathrm{Cl}$ levels exhibited no marked growth responses but increases in $\mathrm{Cl}$ to $280 \mathrm{ppm}$ caused moderate increases in average length and weight of leaves. How- ever, it appeared that an excess of $\mathrm{Na}$ and $\mathrm{Cl}$, cationic unbalance, high osmotic pressure or a combination of these factors (5) reduced the growth and yield at higher sea water concentrations in the later growth stage.

There was an increase in $\mathrm{Na}$ and $\mathrm{Cl}$ content in the leaves in both sand and soil cultures when sea water concentrations were increased to high $\mathrm{Cl}$ levels. The value of the $\mathrm{Na}$ and $\mathrm{Cl}$ content was lower in soil culture than in sand culture. The $\mathrm{Na}$ and $\mathrm{Cl}$ content at 500 ppm was significantly higher than at $250 \mathrm{ppm}$ or less of $\mathrm{Cl}$ in sand culture. There was no significant difference in the $\mathrm{Na}$ and $\mathrm{Cl}$ content below $250 \mathrm{ppm} \mathrm{Cl}$ in soil culture. Also, as compared to sand culture less injury was observed in soil culture. In this experiment it appears to be relationships between the $\mathrm{Na}$ and $\mathrm{Cl}$ content in the leaves and the degree of irjury. However, it is not evident whether or not $\mathrm{Na}$ and $\mathrm{Cl}$ accumulation in the leaves resulted directly in injuries. Ehlig and Bernstein (6) reported that high concentrations of chloride in the substrate caused marginal burn on mature strawberry leaves and sodium also produced some marginal burn. But Osawa (15) stated that direct toxicity from excessive accumulation of $\mathrm{Na}$ or $\mathrm{Cl}$ in plants could not be considered as the primary cause of salt injury in most crops, except strawberry which is sensitive to salt injury. Bernstein and Ayers (1) found that there is no relationship between chloride content in bean plants and salt tolerance.

Osmotic pressure in a medium is also considered one of the causes of salt injury (5). The osmotic pressure in the diluted sea water 
solution and EC value in the soil at the end of the experiment were increased with increasing sea water concentrations. The increments of osmotic pressure and EC value might reduce the growth and yield. Gauch and Wadleigh (8) reported that there was a linear relationship between osmotic concentration of the substrate and reduction in dry weight of the be in plants. Meiri and Kamburoff (14) pointed out that although growth of beans was suppressed similarly by the two types of salinity $\left(\mathrm{NaCl}\right.$ and $\mathrm{Na}_{2} \mathrm{SO}_{4}$ ) when expressed on an osmotic basis, other parameters showed different responses according to salinity type. Masui (12), Smith and Warren(17), Osawa (15) and Yoneda (19) reported that the high EC value was relative to the reduction in yield. High EC values appeared to result in the depression of root development, especially the activity of root hairs, and the absorption of nutrients and water.

LaHaye and Epstein (10) demonstrated that although beans treated with $50 \mathrm{mM} \mathrm{NaCl}$ (which is comparable to about $2,000 \mathrm{ppm} \mathrm{Cl}$ ) were severely damaged in the absence of $\mathrm{Ca}$, the growth at $1 \mathrm{mM}$ Ca was damaged only slightly and at $3 \mathrm{mM} \mathrm{Ca}$ growth was not noticeably affected. As the $\mathrm{Ca}$ concentration increased in diluted sea water solutions, the content of $\mathrm{Ca}$ in the leaves decreased between 500 and 3,000 $\mathrm{ppm} \mathrm{Cl}$ in sand and soil cultures as the content of $\mathrm{Na}$ in the leaves increased. In sand and soil cultures of 0 to $500 \mathrm{ppm} \mathrm{Cl}$ soybean leaf analyses showed an increase in $\mathrm{Ca}$ content, but no interaction between $\mathrm{Ca}$ and $\mathrm{Na}$ was found.

The seed fresh weight and the top dry weight at $0 \mathrm{ppm} \mathrm{Cl}$ were not significantly different with these measurements at $500 \mathrm{ppm}$ $\mathrm{Cl}$ in soil culture. However, they were significantly higher at $500 \mathrm{ppm} \mathrm{Cl}$ in sand culture. In soil culture salt injury was observed to be slight as compared to sand culture. Therefore, it was calculated that $\mathrm{Cl}$ content in diluted sea water at $711 \mathrm{ppm} \mathrm{Cl}$ in sand culture and at $1,339 \mathrm{ppm} \mathrm{Cl}$ in soil culture as compared to $0 \mathrm{ppm} \mathrm{Cl}$ caused a $50 \%$ loss in seed fresh weight. The buffer action in soil may account for the reduction of salt injury in soil as compared to sand culture.

\section{Literature cited}

1. Bernstein, L., and A. D. Ayers. 1951. Salt tolerance of six varieties of green beans. Proc. Amer. Soc. Hort. Sci. $57: 243-248$.

2. $\longrightarrow$, and A. J. MACKENZIE, and B. A. KRANTZ. 1955. The interaction of salinity and planting practice on the germination of irrigated row crops. Soil Sci. Soc. Amer. Proc. $19: 240-243$.

3. $\longrightarrow$ and M. FIREMAN. 1956. Laboratory studies on salt distribution in furrow-irrigated soil with special reference to the pre-emergence period. Soil Sci. $83: 249-263$.

4. - and G. A. PEARSON. 1956. Influence of exchangeable sodium on the yield and chemical composition of plants. 1. Green beans, garden beets, clover and alfalfa. Soil Sci. $82: 247-258$.

5. $\longrightarrow$, and H.E. HAYWARD. 1958. Physiology of salt tolerance. Ann. Rev. Plant Physiol. $9: 25-46$.

6. Ehlig, C. H., and L. Bernstein. 1958. Salt tolerance of strawberries. Proc. Amer. Soc. Hort. Sci. $72: 198-206$.

7. ELLS, J. E. 1963. The influence of treating tomato seed with nutrient solution on emergence rate and seedling growth. Proc. Amer. Soc. Hort. Sci. $83: 684-687$.

8. GaUCH, H. G. and C. H. WADLEIGH. 1942. The influence of saline substrates upon the absorption of nutrients by bean plants. Proc. Amer. Soc. Hort. Sci. 41 : 365-369.

9. KAHN, A., J. A. Goss, and D. E. SMiTh. 1957. Effect of gibberellin on germination of lettuce seed. Science $125: 645-646$.

10. LaHaye, P. A., and E. Epstein. 1969. Salt toleration by plants: Enhancement with calcium. Science $166: 395-396$.

11. LuniN, J., M.H. Gallatin, and A. R. BACHELDER. 1961. Effect of stage of growth at time of salinization on growth and chemical composition of beans. I. Total salinization accomplished in one irrigation. Soil Sci. 91 : 194-203.

12. MASUI, M. 1967. Studies on the fertilization and bed soil management for muskmelon. Tech. Bull., Lab. Hort., Fac. Agr., Shizuoka Univ. Japan. 2:58-68. (Japanese with English summary).

13. - A. NUKAYA, and A. ISHIDA. 1975. Salt content of well water of greenhouse growers in Shizuoka Prefecture. Bull. Fac. Agr., Shizuoka Univ. Japan. $25: 15-22$. (Japanese with English summary).

14. MEIRI, A., and J. KAMBUROFF. 1971. Response 
of bean plants to sodium chloride and sodium sulphate salinization. Ann. Bot. $35: 837-847$.

15. OSAWA, T. 1961. Studies on the salt tolerance of vegetable crops in sand culture. IV. On the relative salt tolerance and the salt injury of vegetable crops with special reference to the mineral nutrition. J. Jap. Soc. Hort. Sci. $30: 241-252$. (Japanese with English summary).

16. OTA, K., T. OGO, and N. OMORI. 1953. Studies on the salt injury on the crop plants. V. The influence of $\mathrm{NaCl}$ solutions upon the germination in wheat. Sci. Rep., Fac. Agr., Okayama Univ., Japan. 2 : 28-37. (Japanese with English summary).
17. SMith, D. E., and G. F. WARREN. 1957. Studies of soluble salts in greenhouse soil. Proc. Amer. Soc. Hort. Sci. $70: 501-511$.

18. WEDDIN, W. F., and B. E. STRUCKMEYER. 1958. Effects of chloride and sulphate ions on the growth, leafburn, composition and anatomical structure of tobacco (Nicotiana tabacum L.). Plant Physiol. $33: 133-139$.

19. YoNEDA, S., and T. KOCHI. 1958. A study on polder soils in Japan. XIII. Determination of electrical conductivity of soil extracts and its use in appraising soil salinity. Sci. Rep., Fac. Agr., Okayama Univ., Japan. $11: 1-14$. (Japanese with English summary)

$$
\begin{gathered}
\text { エダ メの 耐 塩 性 } \\
\text { 糠 谷 明・増井正夫 } \\
\text { 石田 明・小倉孝保 } \\
\text { (静岡大学農学部) }
\end{gathered}
$$

\footnotetext{
摘 要

希䣋した海水が，エダマメの発芽，生育，収量に及ぼ す影響を明らかにするため実験を行なつた，発芽率は， 発芽試験開始 2 日後には海水の $\mathrm{Cl}$ 濃度 0 から 3,000 ppm の間で有意な差がみられなかつた. エダマメを発 芽後 20 日間砂耕栽培した. 地上部の乾物重は, 250 と $500 \mathrm{ppm} \mathrm{C1}$ で最も大であつた. エダマメを土耕と砂耕 で栽培した. 塩害は, 砂耕では 0 と $100 \mathrm{ppm} \mathrm{C1}$ でみら

以上では, 海水の $\mathrm{Cl}$ 濃度が高くなるにつれて塩害は激 しくなつた. エダマメの種子の新鮮重は, 砂耕では0か ら $250 \mathrm{ppm} \mathrm{Cl}$, 土耕では 0 から $500 \mathrm{ppm} \mathrm{Cl}$ で最も大で あつた. 砂耕, 土耕とも海水の $\mathrm{C} 1$ 濃度が高い場合, 葉 の $\mathrm{Na}, \mathrm{Cl}$ 含量は増加した. 土壤の $\mathrm{Cl}$, 置換性 $\mathrm{Na}$ 含 量及び $\mathrm{EC} は$, 海水の $\mathrm{Cl}$ 濃度が高くなるにつれて増加 した.
} れなかつたが， $250 \mathrm{ppm} \mathrm{C1} \mathrm{ではわずかにみられ，それ}$ 